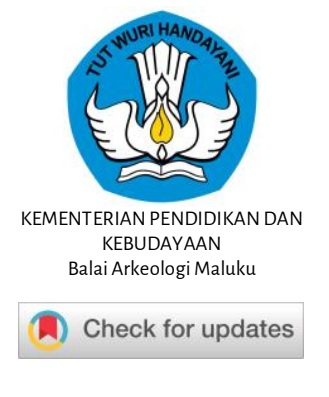

Kapata Arkeologi, 15(1) 2019, 1-14

p-ISSN: 1858-4101, e-ISSN: 2503-0876

KAPATA ARKEOLOGI

SCIENTIFIC JOURNAL OF ARCHAEOLOGY AND CULTURAL STUDIES

Accredited by the Indonesian Ministry of Research, Technology, and Higher Education (RISTEKDIKTI)
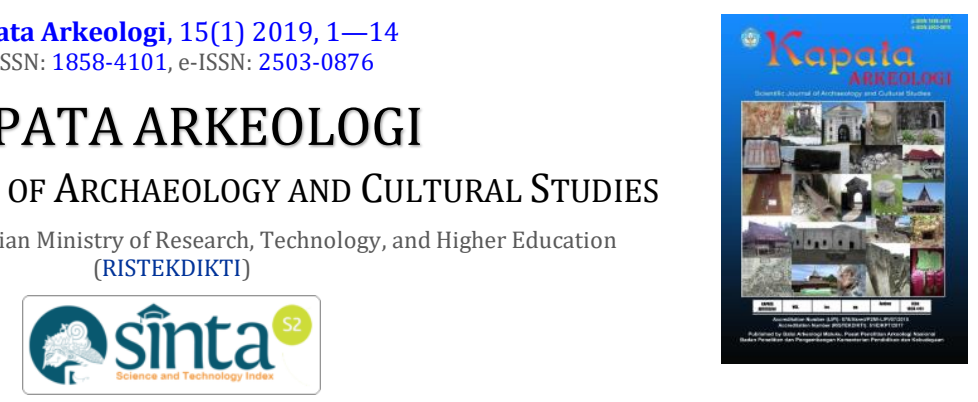

http://kapata-arkeologi.kemdikbud.go.id/

\title{
LOCAL COMMUNity PARTICIPATION IN ESTABLISHING THE Criteria FOR HERITAge SignifiCANCE ASSESSMENT OF THE Cultural Heritage in MEdan
}

\author{
Isnen Fitri $^{1}$ *, Yahaya Ahmad ${ }^{2}$, Ratna $^{3}$ \\ ${ }^{1}$ Department of Architecture, Faculty of Engineering, Universitas Sumatera Utara \\ J1. Perpustakaan, Padang Bulan, Medan 20155, Indonesia \\ ${ }^{2}$ Centre for Urban Design, Conservation and Tropical Architecture, University of Malaya \\ Kuala Lumpur 50603, Malaysia \\ ${ }^{3}$ Department of History, Faculty of Cultural Science, Universitas Sumatera Utara \\ Jl. Universitas No.19, Padang Bulan, Medan 20155, Indonesia \\ *isnen@usu.ac.id \\ Received: 08/09/2018; revisions: $12 / 10 — 25 / 12 / 2018$; accepted: 25/12/2018 \\ Published online: $31 / 07 / 2019$
}

\begin{abstract}
Value is the sole reason underlying heritage conservation. It is self-evident that no society makes an effort to conserve a historic asset what it does not value. Since the publication of the Burra Charter in 1979, many countries recognized the importance of identifying the cultural heritage significance or values to develop the policy and planning in heritage management. Today, the cultural significance assessment is part of the listing process of a historical asset as heritage. Although the discourse of cultural heritage conservation in Medan had evolved since the 1980s, cultural significance assessment is still a new concept for Indonesia heritage community with the absence of its description within the Indonesian Heritage Act No. 11 of 2010 . For that reason, we need a set of criteria which contain principles, characteristics, categories, and guidance to help decide whether a historic asset has heritage value or not and to make the assessment results more accountable, transparent, and consistent as well. Establishing criteria for listing have traditionally been the territory of academics and experts coordinated by the authorities of the region. However, this study has shown that establishing criteria for significance assessment could be done by involving 33 local people through three phases of data collections and analyses such as field survey; in-depth interview; group meeting; and questionnaire to the 33 participants. Finally, the research revealed six criteria for the significance assessment of cultural heritage in Medan derived from five values: history, physical design or architecture, cultural and spiritual, scientific, and social.
\end{abstract}

Keywords: Heritage Significance Criteria; Medan; Local Community Participation; Heritage Value

\section{INTRODUCTION}

The study initially stimulated by the vague listing of Medan's heritage. Until today, most of the cultural activists in Medan are questioning the criteria for listing under the Local Regulation No.6 year of 1988. The absence of inventory, documentation, and value assessment have become the reasons why there have not been any progress in terms of guidelines and policies after the designation. To find answers to this problem, we need to investigate what the rationale is in making national heritage list criteria in Indonesia? These all were discussed by Fitri et al. (2015) in the paper entitled 'Conservation of Tangible Cultural Heritage in Indonesia: A Review Current National Criteria for Assessing Heritage Value.'
Also, interest in this research topic arises in line with the implementation of the decentralization of heritage management in Indonesia, at three levels: national, provincial, and district/city. Each level of administration should prepare and establish their heritage registers, including the municipal government of Medan. Until today, the Medan Municipal Government has not established any explicit criteria for listing. As such, this study will reveal the components of values and criteria for identifying and protecting the cultural heritage, in particular, immovable heritage. In addition to establishing the social heritage criteria for listing, the first step involves documenting the immovable heritage in Medan, followed by evaluating the national heritage list criteria as mentioned under the Indonesia Law No.11 
of 2010. This research will also provide a comprehensive understanding on significance assessment and the process of listing at both national and local levels, as well as improvement of the heritage legislation and management in Indonesia based on the heritage legislation review.

Internationally, professional and scholarly interest in the identification, conservation, and promotion of twentieth-century cultural heritage is growing, yet significant works of the era are underrepresented on heritage registers from local inventories to the World Heritage List (Macdonald \& Ostergren, 2011: 1). This awareness is also experienced by many scholars and heritage professionals in Asian countries, including Indonesia, over the past decades. Burra Charter has been adopted as the standard for best practice in the conservation of historic environment particularly in Australia, New Zealand, Canada and many developed countries in Latin America, North America, Europe, and Asia. The Hoi An Protocols (Engelhardt, 2009) which is signed by professionals representing the heritage from Asia countries serves as a guideline of the cultural significance adopted from Burra Charter. Also, The Principles for the Conservation of Heritage Sites in China, known as China Principles (China ICOMOS, 2015) is inspired by Burra Charter.

Nevertheless, the Indonesian government has not adopted the Burra Charter; therefore, the concept of cultural heritage significance has not yet elaborated in the heritage legislation. They are starting to realize the importance of conserving their cultural assets and have transferred this awareness to a broader community. As a result, it has influenced the improvement of heritage protection for each bureaucracy. It can be traced back from the increase in the number of charters, guidelines, and declarations issued during the last three decades mainly in Asia which had an impact on the regional, national, and local levels. From the early 1980s, aspects of heritage significance had become famous in the discourse of cultural identity, the spirit of a place, sustainable development, and community involvement. As mentioned in the Burra Charter (2013), conservation must also be carried out to preserve the values and significance of place, establishing urban character and identity. For instance, the term 'cultural significance' is not something new. As stated in Venice Charter (1964), the term has expanded rapidly since the Burra Charter was published. Although the Burra Charter was first set up to guide practitioners such as archaeologists, historians, architects, engineers, and planners, it is also a useful document for others. It means that anyone participating in the care of significant places will make better, more informed decisions if they understand the Burra Charter. For that reason, Zancheti, Hidaka et al. (2009: 47) asserted to identify and retain the cultural significance, which has been the primary objective of heritage conservation management and projects over the last 30 years. Later, the issue of cultural heritage significance assessment continues and develops along with the increase of heritage professionals globally. Since the recent decades, many countries have recognized the importance of identifying value, so that this conservation process often referred to other countries as 'management based heritage significance' or 'values-based heritage management.' A conservation plan based on significance is a helpful first step in making decisions about what and how to conserve it and considered a positive move towards a more transparent and coherent approach to cultural-heritage management (Clark, 2014).

Like those mentioned above, the value is a sole reason underlying heritage conservation. It is selfevident that no society makes an effort to conserve a historical asset that it does not value. Since the publication of the Burra Charter in 1979, many countries recognized the importance of identifying the cultural heritage significance or value to develop the policy and planning in heritage management. Today, the cultural significance assessment is being part of the designation of a historical asset as heritage. When identifying the heritage significances, we need a set of criteria which contain principles, characteristics, categories and guidance to help decide whether a place has heritage value or not and to make the assessment result more accountable, transparent, and consistent as well. Recognition of cultural heritage and establishing of criteria for listing have traditionally conducted by academics and cultural-heritage experts in cooperation with the authorities of the region. To be included in the listing, the nomination must set out the qualities or values that make it outstanding to the nation/state by indicating how it meets one or more of the numbers of National/Provincial/Municipal criteria. This paper correlates and establishes the criteria of heritage significance assessment through the participation of the 33 local people in Medan, one of the capital city in Sumatra, Indonesia which has abundant urban heritage, especially architectural heritage. The participants represent the various communities of the nongovernment organizations, custodians or managers, the professional institutions and local government officers who are responsible for the heritage conservation.

\section{The Importance of Heritage Significance Assessment in Cultural Heritage Protection and Management}

The term cultural significance vividly first described in the Burra Charter in 1979, this concept, in brief, defined as the "aesthetic, historical, scientific, social or spiritual value for past, present or future generations." 
Accordingly, significance means "embodied in the place itself, its fabric, setting, use, associations, meanings, records, related places, and related objects" (AICOMOS, 2013). Besides, the term 'cultural significance' of this charter used as a synonym for cultural values and asserted that encompassed in such sites, in their fabric, uses associations, meanings, and memories. During more than three decades, many countries around the world have adopted the conservation process of the Burra Charter with certain adapting to the administrative structure of their countries. It currently has become the best-known guideline for heritage significance assessment. Today, the cultural significance assessment is part of the designation or labeling historical asset as heritage. The creation of heritage indicates the difference between those who subscribe to it from those who do not. In this context, cultural heritage valuation becomes a tool to get better understand the significance of heritage to different sections of society.

Nevertheless, this is not the only reason why we need to value our cultural heritage in which to understand, to preserve, and to manage our heritage. The valuation process also intends to assess existing values as attached by the relevant population. However, the final aim in the context of policy analysis is to significantly achieve the valorization of our heritage, in other words, to add new values to the existing ones (Riganti \& Nijkamp, 2004: 1). As the arguments of O'Connor (2011: 189) and Tomback (2007: 209), the benefit of applying the evaluation process to cultural heritage is a significant step beyond identifying places of cultural significance as it provides a basis for decision making with short and long-term conservation and maintenance. Accordingly, it is noteworthy that valuation represents a crucial step in the management of cultural heritage, especially when we narrow the concept to the built environment.

Regarding the process in Burra Charter, the sequence of investigations, decisions, and actions are started by understanding the cultural significance, then developing a policy and finally administering or managing the heritage asset following the policy. Kerr (2013: 4) explained that cultural heritage significance aims to help in identifying and assessing the attributes that describe why a historical asset being necessary or valuable for us or society. An understanding of it is, therefore, essential to any planning process. Afterward, he emphasized the process as a necessary sequence in conservation planning, which naturally consisted of two stages. The first stage covers the gathering and analysis of evidence and the assessment of significance - the second concerns about developing a conservation policy and setting out strategies for its implementation. To achieve the purpose of conservation, Zancheti, et al. (2009: 49) criticize that the procedures or process should not be performed in isolation from each other, but instead they must interact.
They also suggest some procedures must repeatedly be conducted while consultations with stakeholders; further investigations are also necessary. Later, they recommended that the process must follow four steps to get a better understanding of cultural significance. Firstly, identifying and defining the site, its fabric, and associations, then securing it and making it safe; secondly, gathering and recording adequate information (whether physically, orally or in document form) so as to understand the significance of the site; thirdly, assessing the significance; and lastly, preparing and developing the statement of significance. In a similar vein, Lithgow \& Thackray (2009) proposed three main steps in the process of studying and understanding the meanings and values of places, objects and collections as follows: first, analyzing the object or resource; second, understanding its history and context and third, identifying its value for the communities which created and/or care for it.

Referring to the conservation process diagram within Burra Charter, understanding the significance of historical asset is unable to proceed without gathering and recording its information. Furthermore, creating a record of the cultural heritage asset is part of the process of establishing its significance and of managing the care and protection of the heritage. Due to this reason, it would be preceded by conducting an inventory or documentation before significance assessment (Orbasly, 2008: 94-95). Most heritage experts asserted the essential of inventory and documentation for a conservation project, as the argument of Rand \& Chabbi (2007: 3) which refers to "documenting of cultural heritage is a critical component of the conservation planning process which can provide a long-term foundation for the maintenance, management, and monitoring of a site." In a similar vein, ICOMOS (1996) emphasized that recording or documentation of cultural heritage is the best way to get an understanding of its significance, therefore, it is essential to acquire knowledge getting advance understanding of its values and evolution. Indeed, inventory has long been discussed since 1931 as mentioned in Athen Charter [Article VII (c)] on the value of international documentation, where each country or the institutions are recommended to establish an inventory of ancient monuments, with photographs and explanatory notes. Therefore, proper documentation and significance assessment is part of the package for the initial step in conservation work to identify, ensure, and understand the cultural asset that will be passed on to future generations.

Also, to obtain the purpose, it is essential to keep precise records of decisions, and changes to the historical asset help in its care, management, and interpretation. While, in term of the approach, Avrami et al. (2000: 910) and O'Connor (2011: 189) asserted the methodological approach to value assessment proposed 
must be flexible - the ideas, plans and also the process should be transferable, transparent, useful, balanced, and fair. Therefore, the cultural heritage valuation should not apply a general assessment technique or an unambiguous approach that has universal validity, but it has to be performed by tailor-made methods that address the classification of cultural assets.

\section{Local Community Participation in Heritage Significance Assessment}

In recent decades, the new groups which do not include heritage specialist and experts are emerging in line with the expanding and evolving concept of heritage. These groups are citizens or local communities, of professionals from other fields such as economics, political, and tourism, and of representatives of special interests in the heritage field. These new groups have participated in and supported many heritage programs. It is notably evident in the growing number of people who, in many countries, visited historic buildings and districts which make up the critical part of the heritage (Jokilehto, 2005).

Nevertheless, people's involvement is merely an instrument and rarely a goal. UNESCO experiences while carrying out the process of inclusion for listing revealed that the concept of OUV is often poorly understood and need to improve with communication at the site level. Accordingly, it is recommended that the identification of OUV requires "extensive participation by stakeholders, including local communities and indigenous people." Besides, the 1987 Washington Charter/ICOMOS emphasized that the participation and involvement of the local people are essential to the success of the conservation program and should be encouraged. As such, the conservation of historic towns and urban areas is a must, first of all, involves their residents (ICOMOS, 1987).

The word 'public or community' has a broad meaning and is involved. A simple understanding of these aspects refers to what was stated by Davidoff in 1965 (Clark, 2014) quoted from Dian \& Abdullah, (2013): 'communities as local people who are either individuals or organizations have an interest in or likely to be affected, either positively or negatively, with a decision to be made on any certain issues by the authorities.' Appiah (2006) and Johnson (2000) in Chirikure et al. (2008) explained: 'community is a body of people inhabiting the locality.' Furthermore, he explained in his paper that the community, which is base on interests, is called stakeholders. Previously, the archaeologist and heritage managers argued that the local communities are regarded as a source of cheap labor for fieldwork instead of consumers with knowledge of the past. Local people are often viewed as troublemakers.
Therefore, the archaeologists and heritage managers are trying to protect sites from the neighborhood (Chirikure et al., 2008). At present, the implementation of the method is in line with the development of the global trend in heritage conservation that is still devoted to knowledge rather than to community interest. In contrast to archaeology, to the disciplines of architecture, history, and anthropology had already positioned the public as consumers of knowledge of the past.

Up to the date, planning and managing the heritage asset was often seen as exclusively a job for the expert. Involvement of ordinary people has often been limited. Therefore, developing an understanding of local historic assets can be an effective and powerful way of increasing public awareness and participation (English Heritage, 2008: 316 - 317). The question about 'stakeholders' is an essential issue in value assessment. Thus, identifying the social and implying approaches designed to reach and hear them in light of their particular identity and capacity are required for any methodology for heritage value assessment (Mason, 2008).

Nonetheless, there are many challenges to involve the people in heritage conservation, such as the experience and mindset, even the background of the people leading individuals and groups are unable to collaborate well. UNESCO Nairobi Recommendation (1976) described that there was a method to establish constant cooperation between communities and individuals at all level in safeguarding heritage as follows:

(... information adapted to the various of individuals concerned; surveys adapted to the persons questioned; establishment of advisory groups attached to the planning teams; representations of the owners, occupants, and managers in advisory function on bodies responsible for decision-making, management and organization of operations associated with a plan to protect, or the creation of public corporations to play a role in the implementation of the plan.)

According to the World Bank (1994), the level of public participation categorized into two levels: low and high. Low-level participation still applies a one-way communication such as sharing information or consultation.

Nevertheless, the high-level participation would be achieved by collaboration and empowerment in the transfer of control over decisions/resources. Accordingly, the high level of participation in heritage conservation will make conservation efforts more sustainable. Herb Stovel (2002) asserted in his article that quoted by Zerrudo (2008), community involvement improves the understanding of heritage and associated meanings; encourages social cohesion and sustainability, and work towards a shared vision at a local level. Then he described heritage belongs to the society, not to 
authorities and community organizing like community consultations, leadership training, team building, heritage orientation, local history seminars are fundamentally bonding together the community stakeholders towards a universal emotion, understanding, and valuation of the heritage.

The contemporary trend in heritage conservation theory today emphasizes the role of community in the cultural significance assessment is essential. In conclusion, there are several benefits to community participation in heritage conservation as the following paragraphs:

- Participation encourages community stakeholder to voice their needs and issues. Outsiders are never able to determine the best needs of any community without consulting first with the community.

- Participation encourages social cohesion and sustainability and works towards a shared vision and a universal emotion.

- Participation builds trust, confidence, and self-worth as community members recognize the importance of their knowledge and ideas in solving the issues in heritage conservation through consensus on areas of work.

- Participation improves the understanding of heritage and associated meanings as well as builds technical and interactive skills of community members as they begin to work together collaboratively on problems articulated.

- Participation respects local knowledge and knowhow in the design of projects or interventions as well as creates the conditions for sustainability.

- Participation encourages community members to organize around problem identification and solutions by strengthening a community to take action to solve its problems.

The issue of cultural heritage conservation in Sumatra Island, especially in Medan, had started in the 1980s; however, it spread out rapidly since the establishment of Badan Warisan Sumatra (BWS) or Sumatra Heritage Trust in 1998. According to its vision, BWS ideally serves and manages the heritage conservation issue and work in Sumatra Island. Therefore, it encouraged the establishment of other heritage conservation's NGO in West Sumatra, BangkaBelitung Island, Jambi. It established a network for heritage conservation in Sumatra, namely Pan Sumatra Network in 1999. Since establishment the other organizations, the scope of activity of BWS also covers heritage conservation in Sumatra. Up to the date, the awareness of the community in Medan can be seen by the activities and the increased number of heritage organization in town. Several local communities in Medan led by BWS protested to the local government over the demolition of historic buildings that have high historical and architectural values such as the Mega Eltra building (2002), villas on Jalan Diponegoro (2010), Beringin Park (2014), and the Esplanade or locally known as Lapangan Merdeka (2014-2018). In the last four years, there are twelve organizations formed a coalition locally called Koalisi Masyarakat Sipil Medan (KMS) have been struggling to save the Esplanade of Medan that is going to be chaos and losing its character and historical value.

\section{MeThOdS}

The study is involved in collecting, analyzing, and integrating quantitative (field survey and questionnaire) and qualitative (interview and group discussion meeting) data. The single case study by using participatory community approach. Following the recommendations of the conservation charters published in the past 50 years to promote the role of the community. The participation of local people is not only to get their inputs but also to engage the local community in establishing the criteria for better protection and conservation of their cultural heritage in the future. The inventory of the immovable heritage began in 2010, continued in 2012 and was updated in 2014. All the previous inventories done by other scholars or organizations were compiled before carrying out the field survey to update the inventories. Three seasons of field surveys done in 2010, 2012, and 2014. Another study focused on establishing the local assessment criteria for cultural heritage in Medan was done by the author. At the end of September of 2014, after completing documentation, it is immediately followed by conducting the second group discussion meeting to assess the cultural significance of sampling using the new criteria. The significance assessment involved 50 local people to validating and strengthening the new criteria.

Before creating the assessment criteria, three essential steps carried out: firstly, a literature review was done to gain a comprehensive understanding and interpretation of the cultural significance assessment. It was then followed by identification and documentation of the cultural heritage of Medan through field survey aimed at identifying the character and significance of Medan's heritage that was discussed in a paper by the author published in the proceeding of the $2^{\text {nd }}$ International Nusantara Cultural Heritage (2017). The results of the inventory on the immovable cultural heritage in Medan will use for setting up the criteria for cultural significance assessment. The next step was a critical review of the national heritage criteria stated under the Article 5 of Indonesia Law No.11 of 2010 (Undang-Undang RI, 2010) by interviewing the respondents to obtain their opinions on the assessment 
criteria which should be constructed for the evaluation of nominated historical assets in Medan. The recommendation of this review as mentioned in Fitri \& Yahaya (2017) will be the foundation for setting up the criteria for the significance assessment of the cultural heritage in Medan by inviting the participants in group discussion \& meeting using a Nominal Group Technique followed by questionnaires to the research respondents. In order to gain maximum benefits, the community should be involved from the beginning of conservation work, starting from gathering of information to managing the heritage asset as shown in Figure 1.

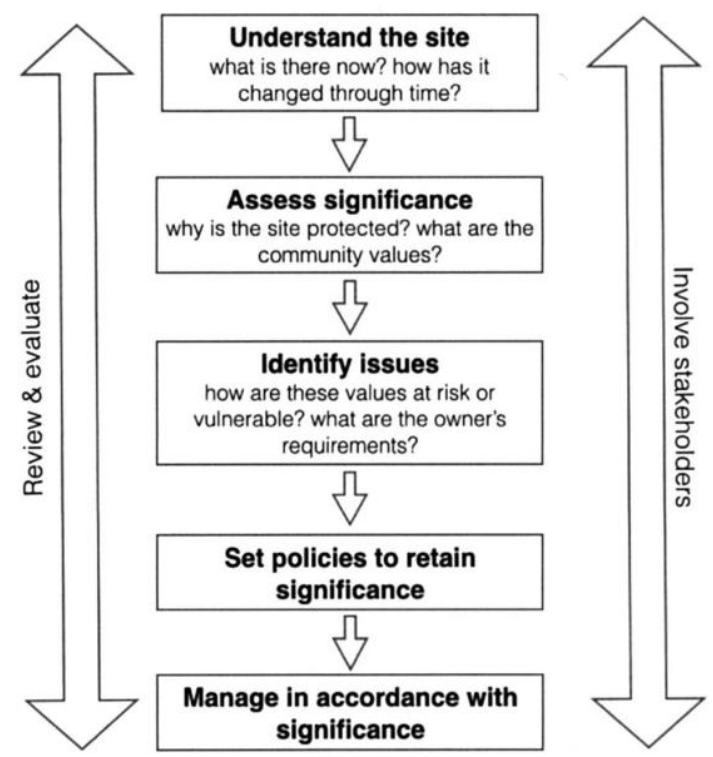

Figure 1. Community involvement during the conservation process

(Source: Adopted from Clark \& Maeer, 2008)

\section{Result AND Discussion}

Avrami (2000: 7-8) pointed out that cultural significance was the term that the conservation community has used to encapsulate the multiple values ascribed to objects, buildings, or landscape. Before gauging the value of cultural heritage, it was essential to benchmark the components of values. This identification and ordering of values serve as a vehicle to inform decisions about how best to preserve these values in the physical conservation of the object or historic asset.

The assessment will issue a Statement of Significance (SOS). During the process of assessment in Australia for instance, if an SOS is not comprehensive enough then the listing is not thorough in its analysis, suggesting that it is advisable to develop it for approval by the authority (Australian Heritage Council, 2010). Hence, an SOS for a cultural asset is a crucial document in determining goals, standards, and techniques that are appropriate for safeguarding the historic environment in the future. This cultural significance statement is also crucial for developing conservation policy, strategy, and planning. According to the literature review, there are many kinds of value types and the interactions among them are so complicated as summarized by the experts, organization, and charter or convention, as shown in Table 1. This part delves into classifying the notion of value as a guiding idea in cultural significance assessment. Mason (2002), in his paper, 'Assessing Values in Conservation Planning: Methodological Issues and Choices' wrote the term characterization of cultural heritage value had been first discussed from art-historic view in 1902 by Alois Riegl. According to the table compiled by Mason on the development of heritage value, Riegl stated that five values should be considered in the evaluation of the heritage value of age, historical, commemorative, use, and art. This typology then compared with the characteristics of important heritage value are reviewed by several experts and organizations, expressed by an archaeologist, William Lipe (1984), Bruno S. Frey from economic view (1994), the Burra Charter (first in 1979, the latest revision in 2013), The New Zealand Charter (2013, first published in 1992), and English Heritage (1997). Later in 2008, the English Heritage proposed a typology of values headings, which explained as evidential, historical, aesthetic, and communal values (English Heritage, 2008).

Table 1. Typology of values based on the theoretical concept

\begin{tabular}{|c|c|}
\hline Reigl (1902) & $\begin{array}{ll}\text { - } & \text { Age } \\
\text { - } & \text { Historical } \\
\text { - } & \text { Commemorative } \\
\text { - Use } \\
\text { - }\end{array}$ \\
\hline Feilden (1982) & $\begin{array}{ll}\text { - Emotional } \\
\text { - Cultural } \\
\text { - Use }\end{array}$ \\
\hline Lipe (1984) & $\begin{array}{l}\text { - Aesthetic } \\
\text { - Associative-symbolic } \\
\text { - Economic } \\
\text { - Informational }\end{array}$ \\
\hline $\begin{array}{l}\text { Feilden \& Jokilehto } \\
\text { (1993) }\end{array}$ & $\begin{array}{l}\text { Cultural Values: } \\
\text { - } \text { Artistic or technical } \\
\text { - Rarity } \\
\text { Contemporary socio-economic: } \\
\text { - Economic } \\
\text { - } \quad \text { Functional } \\
\text { - Educational } \\
\text { - Social } \\
\text { - Political }\end{array}$ \\
\hline Frey (1997) & $\begin{array}{ll}\text { - } & \text { Monetary } \\
\text { - } & \text { Option } \\
\text { - } & \text { Existence } \\
\text { - } & \text { Bequest } \\
\text { - } & \text { Prestige education } \\
\end{array}$ \\
\hline $\begin{array}{l}\text { English Heritage } \\
\text { (England, 1997) }\end{array}$ & $\begin{array}{ll}\text { - } & \text { Cultural } \\
\text { - } & \text { Resource } \\
\text { - } & \text { Recreational } \\
\text { - } & \text { Aesthetic } \\
\text { - } & \text { Economic-importance }\end{array}$ \\
\hline Thorsby (2006) & $\begin{array}{l}\text { - Aesthetic } \\
\text { - Spiritual } \\
\text { - } \text { Social } \\
\text { - Historical } \\
\text { - Symbolic } \\
\text { - } \text { Authenticity }\end{array}$ \\
\hline
\end{tabular}




\begin{tabular}{lll}
\hline Burra Charter (the & - & Aesthetic \\
latest revision 2013) & - & Historic \\
& - & Scientific \\
& - & Social or \\
& - & Spritual \\
\hline New Zealand Charter & - & Historical \\
(the latest revision & - & Archaeological \\
2013) & - Architectural \\
& - Technological \\
& - Aesthetic \\
& - Scientific \\
& - Spritual \\
& - Traditional \\
& other special cultural \\
& significance, associated with \\
& human activity \\
\hline Source: Adapted and modified from Mason 2002: 9; Worthing \\
\& Bond 2008 &
\end{tabular}

By looking the values mentioned above, therefore, Mason argued it was clear that there are several distinct, if not entirely separable, categories of heritage value: historical, spiritual, political, educational, aesthetic, artistic and economic. All characteristic of value are summarized to have similarities, and there are only a few points of view and different ways. While, in its Guidelines to the Burra Charter: Cultural Significance (1984), it is mentioned that the categorization of value into an aesthetic, historical, scientific, and social value is one approach to understanding the concept of cultural significance. In the Burra Charter, for instance, economic value is minimized because they are seen as a derivation from the cultural and historical values of and are, therefore, given as secondary consideration.

In the earlier, the discussion of values focused on the distinction between the tangible and intangible value. The tangible value is commonly defined as the intrinsic value, perceived as unchanged or do not require modification and universally existed in cultural properties. While, the intangible value is called the extrinsic value, which is constructed by personal, social, and cultural perspective and is therefore inherently subjective. Often, intrinsic values can be assessed objectively, and hence, the significance level attributed to them can gain widespread agreement. Architectural design value or tangible value in roommate's structure of the building is often perceived as intrinsic value. However, cultural heritage values are not constant and could be changed over time as well as highly influenced and shaped by a contextual factor such as culture trend, social and economic imperatives. Thus, the distinction between intrinsic and extrinsic values is seldom discussed by heritage experts and scholars.

By using such a typology — a framework that breaks down significance into constituent kinds of heritage value - the views of experts, citizens, communities, governments, and other stakeholders can be voiced and compared more efficiently. The breakdown is also oriented to conservation practices as categories focusing on how the heritage value is used and evaluated (contingent, and by public other than the elite and expert), while many other characteristics resonate more with connoisseurship and professional values and strongly influenced by the idea of the value the natural heritage. Furthermore, he concludes two significant types of values; those are socio-cultural values and economic values as alternative ways of understanding and labeling the same, wide range of values. The socio-cultural values have subcategories which are not distinct, exclusive, and quite overlapped extensively. In contrast, the subcategories under economic values intended to distinct and exclusive of one another (see Figure 2).

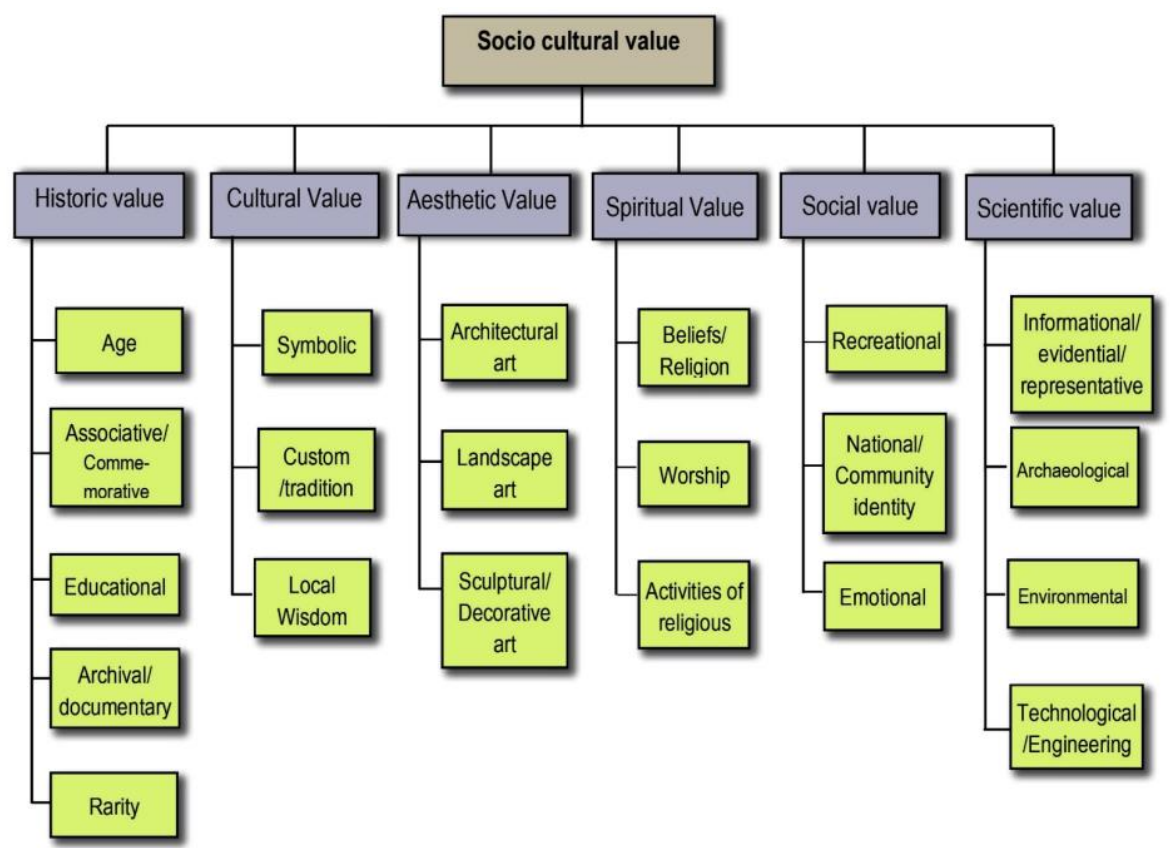

Figure 2. The Schematic for Values Typology Based on the theoretical concept (Source: Compilation of Value Types from Mason, 2008; Worthing \& Bond, 2008) 
During two decades, many countries have amended their legislation and accommodate the concept of cultural significance assessment in the process of establishing a heritage register. In order to obtain comprehensive types of values in the heritage practice, this study compiled the heritage values and criteria applied for the eight countries starting from England, United States of America, Canada, New Zealand, Australia, Malaysia, South Africa, and Vietnam collected from the Heritage Act for each country. The reason to select these countries is that they have accepted the concept of cultural significance assessment of the Burra Charter, perhaps excluded the USA.

Compare to the schematic of value types according to the literature review; it is found that the historical value, aesthetic value, scientific and cultural value as well as social associative value are central values types. It is identified by the eight countries as samples to be included in the listing while social and cultural values are quite overlapping in the statement of criteria. It needs to read the principles and guidelines carefully to know what exactly value meant by the Acts. Because it is very often, these values were linked to the historical value. While no countries of the eight countries as the samples that are applying the best practice criteria for listing defined that economic value as one the criterion for inscription in the listing. Therefore, it can be illustrated the schematic values for the best practice in the listing applied by the eight countries, as shown in Figure 3. Those values types are identified from the determined criteria, as stated in their Heritage Act. It is referring to Table 2.iv and 2.v, this summarized that there are 12 criteria determined by the eight countries ranging from historical to integrity. It seemed that criterion 'history' is dominant, followed by aesthetic and social associative. The most criteria defined by the eight countries, hold the type of values: historical, aesthetic, scientific, and cultural as well as social associative, as shown in Figure 4.

Compare to the schematic of value types based on the theoretical concept; it was found that the historical value, aesthetic value, scientific and cultural value as well as social associative value are central values types identified by the eight countries as samples to be included in the listing. While social and cultural values are quite overlapping in the statement of criteria. It needs to read the principles and guidelines carefully to know what exactly value meant by the Acts. Because it is very often, these values were linked to the historical value. While no countries of the eight countries as the samples that are applying the best practice criteria for listing defined that economic value as one the criterion for inscription in the listing. Therefore, it can be illustrated the schematic values for the best practice in the listing applied by the eight countries.

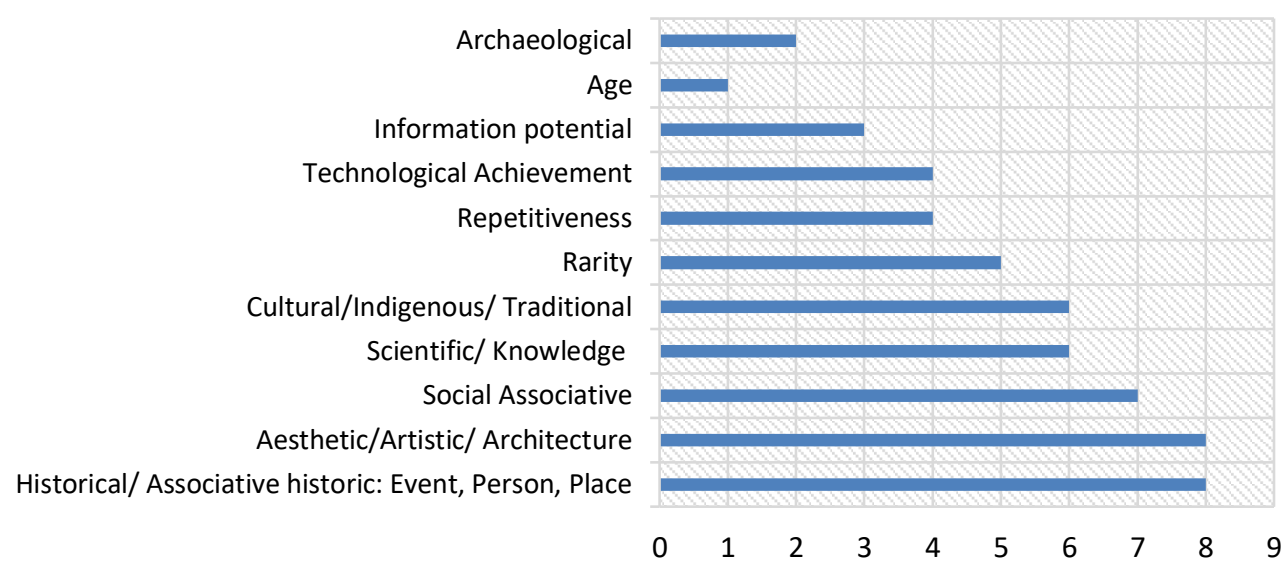

Figure 3. The value types according to the eight countries (Source: Authors, 2018)

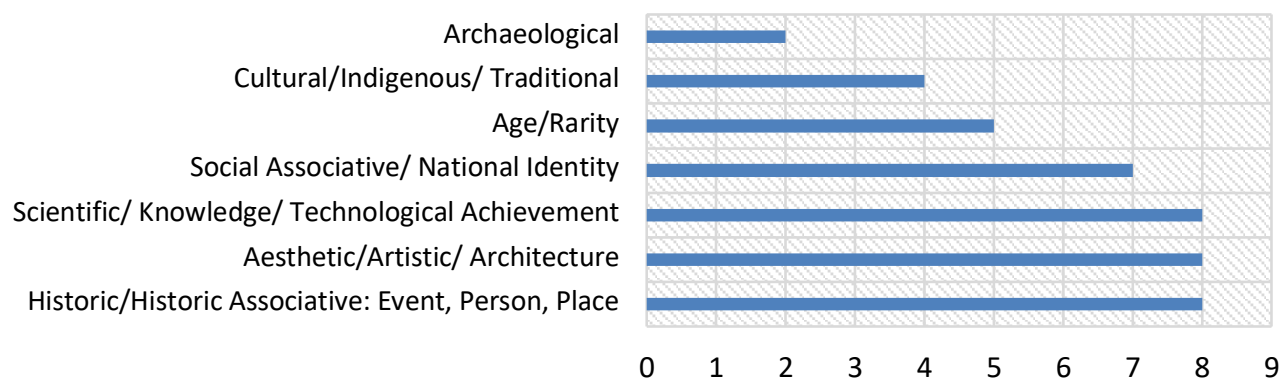

Figure 4. The assessment criteria according to the eight countries (Source: Authors, 2018) 


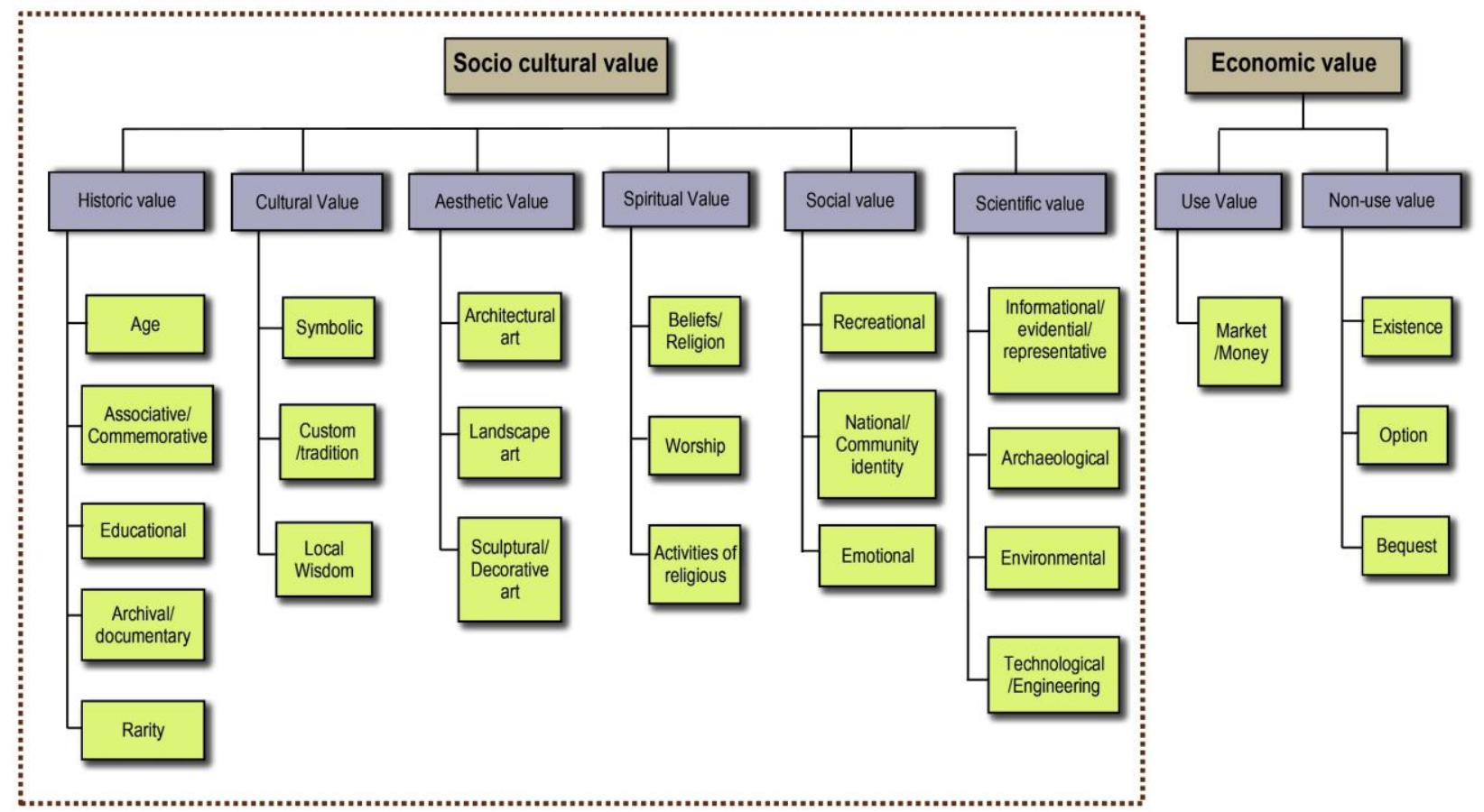

Figure 5. The Schematic of Values and its subcategories for the best practice for the listing process (Source: Authors, 2018)

The analysis for establishing the criteria of significance assessment for the cultural heritage in Medan after reviewing the national criteria divided into four steps: (i) interview; (ii) group discussion meeting; (iii) the questionnaire; and (iv) the second group meeting as shown in Figure 6.

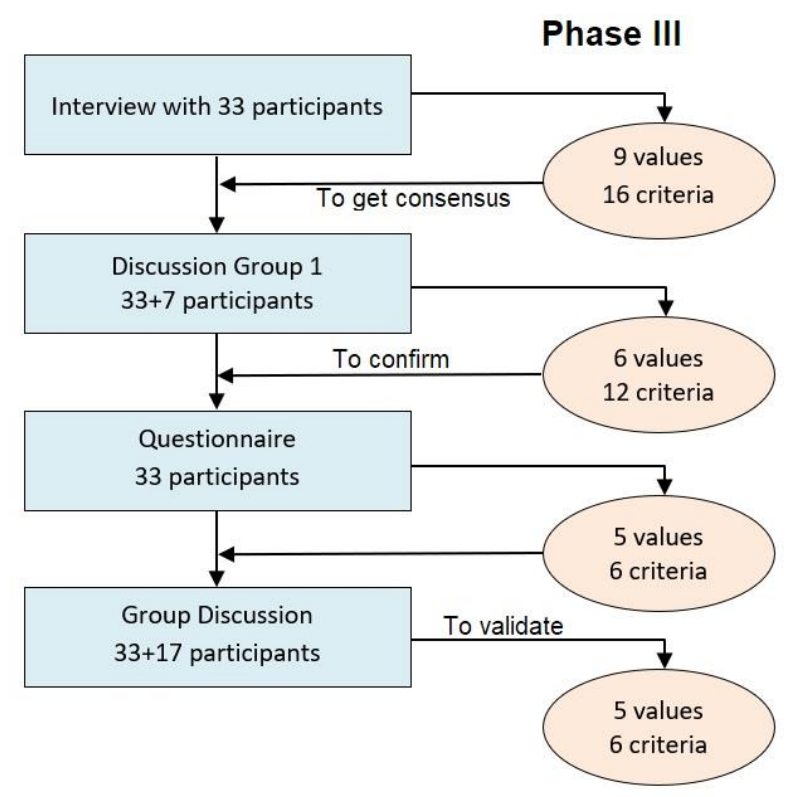

Figure 6. The process of establishing the assessment criteria (Source: Authors, 2018)

\section{Interview}

The in-depth interviews with the 33 participants were conducted between December 2013 and January 2014 after carrying out the field survey and literature review. The study applied the semi-structured interview with open-ended questions because more specific issues can be addressed. There were two parts of questions during the interview section as follows: first, the review of the national criteria stated in the Indonesia Law No.11/2010. The second is the questions to establish the criteria for significance assessment on immovable heritage in Medan.

The four questions of the first part interview are as follows:

1. The value types to include in national criteria;

2. The importance of education value to be included in the national criteria

3. The review of each criterion of the national criteria stated in article 5 of the law No.11 the year 2010 .

4. The minimum number of criteria that must meet in order to include in the listing

These questions are addressed to review national criteria for assessing heritage value of Indonesian tangible cultural property designating as heritage based on Law of Cultural Properties No. 11 of 2010 mentioned as follows: first, must have the age at least 50 (fifty) years or more; second representing the style with the minimum aged 50 (fifty) years; third, having a significant meaning for history, science, education, religion and/or culture, and fourth, having cultural value that can strengthen cultural identity of the nation (Undang-Undang RI, 2010). The second section of the interview has two questions, first is to determine the value types that should meet by the historic assets for inclusion in heritage listing of Medan and second is to derive the criteria for assessment from the proposed value types. 
The results of the interviews revealed nine critical values (see Figure 3). Based on the interview, there were 16 criteria proposed by the 33 participants, as shown in Table 1.

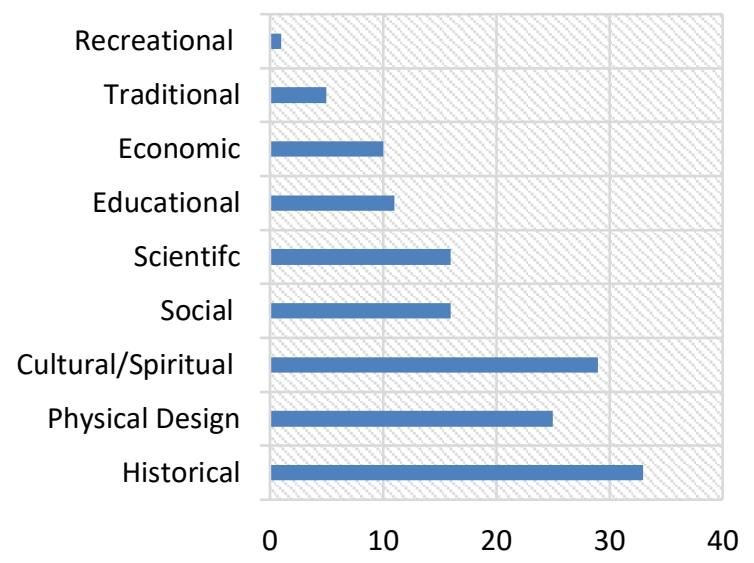

Figure 7. Value Types based on interview results (Source: Authors, 2018)

Figure 7 shows that there are nine critical values represented by the personal views of the participants. These values are summarised from the 16 criteria, as shown in Table 2.

Table 2. Assessment Criteria for cultural significance based on interview results

\begin{tabular}{|c|c|}
\hline \multicolumn{2}{|r|}{ The Range of Criteria } \\
\hline i & $\begin{array}{l}\text { It has a strong connection with an important person, } \\
\text { workplace of an important person; events and activities } \\
\text { that are important parts and contribute to the historical } \\
\text { and cultural of Medan city. }\end{array}$ \\
\hline ii & $\begin{array}{l}\text { It is the creation of one designer or architect who is } \\
\text { significant for the community. }\end{array}$ \\
\hline iii & It possesses uncommon, rare or endangered aspects. \\
\hline iv & $\begin{array}{l}\text { It has the potential to increase patriotism and national } \\
\text { consciousness. }\end{array}$ \\
\hline $\mathrm{v}$ & $\begin{array}{l}\text { It has the potential in strengthening the nation's } \\
\text { character. }\end{array}$ \\
\hline vi & $\begin{array}{l}\text { It demonstrates high achievement of creativity or } \\
\text { technology at a particular period. }\end{array}$ \\
\hline vii & $\begin{array}{l}\text { It has the information potential that will contribute to the } \\
\text { understanding of history and culture and is useful in the } \\
\text { present. }\end{array}$ \\
\hline viii & $\begin{array}{l}\text { It has a strong or special association with a particular } \\
\text { community or cultural group in aspects of social, cultural, } \\
\text { or spiritual. }\end{array}$ \\
\hline ix & It has potential specific local traditions. \\
\hline$x$ & $\begin{array}{l}\text { It represents the identity or symbolism and interests of } \\
\text { ethnic and cultural diversity. }\end{array}$ \\
\hline$x i$ & It is accessible to the public (open to the public). \\
\hline xii & $\begin{array}{l}\text { It demonstrates the aesthetic and characteristics that are } \\
\text { considered important. }\end{array}$ \\
\hline xiii & $\begin{array}{l}\text { It shows the main characteristics or specific } \\
\text { environment/symbolic/ritual of the classification of } \\
\text { cultural heritage. }\end{array}$ \\
\hline xiv & It has the potential to be a landmark. \\
\hline$x v$ & $\begin{array}{l}\text { It has the economic potential to enhance the } \\
\text { development of the town. }\end{array}$ \\
\hline xvi & It has a recreational function. \\
\hline
\end{tabular}

Source: Authors, 2018

\section{The First Group Meeting}

The values types from the interview results were reduced to eight after a discussion with participants in a forum by combining the traditional values with the cultural values. At the first group discussion meeting, 16 criteria were revised and reduced to 12 criteria by combining the archival record and archaeology with criteria on (vii): information potential. Then the criterion symbolic is combined with criterion $(\mathrm{x})$ : representing the identity and interests of ethnic and cultural diversity. The FGD is summarized into eight values as the interview result excluded the traditional value. According to the participants, it is to avoid overlapping with the cultural and spiritual values which were intended to include in the traditional value. The 12 criteria for FGD are presented in Table 3.

Table 3. Criteria for cultural heritage significance assessment based on the group discussion meeting result

\begin{tabular}{|c|c|}
\hline \multicolumn{2}{|r|}{ The Range of Criteria } \\
\hline $\mathrm{i}$ & $\begin{array}{l}\text { It has a strong association with events that have played } \\
\text { an important part and contributed to the historical and } \\
\text { cultural development of Medan city. }\end{array}$ \\
\hline ii & It possesses uncommon, rare or endangered aspects. \\
\hline iii & $\begin{array}{l}\text { It has potential information that will contribute to the } \\
\text { understanding of the cultural history of Medan and } \\
\text { science so that it can be utilized for the present. }\end{array}$ \\
\hline iv & $\begin{array}{l}\text { Demonstrating specific local tradition and representing } \\
\text { the identity or symbolism of ethnic and cultural } \\
\text { diversity. }\end{array}$ \\
\hline $\mathrm{v}$ & $\begin{array}{l}\text { It is exhibiting aesthetics and characteristics that are } \\
\text { considered important for Medan city. }\end{array}$ \\
\hline vi & $\begin{array}{l}\text { Demonstrating main or principal characteristics of } \\
\text { classification of cultural heritage in Medan. }\end{array}$ \\
\hline vii & $\begin{array}{l}\text { Creation of product of a designer, architect, builder, } \\
\text { and artist that have played an important part and } \\
\text { contributed to the historical and cultural development } \\
\text { of Medan city. }\end{array}$ \\
\hline viii & $\begin{array}{l}\text { It has a strong or special association with an important } \\
\text { person, in particular, a community or cultural group in } \\
\text { aspects of social, cultural, or spiritual. }\end{array}$ \\
\hline ix & $\begin{array}{l}\text { It has the potential to increase and strengthen } \\
\text { patriotism, national consciousness, and character. }\end{array}$ \\
\hline$x$ & $\begin{array}{l}\text { Demonstrating high achievement of creativity or } \\
\text { technology at a particular period. }\end{array}$ \\
\hline $\mathrm{xi}$ & $\begin{array}{l}\text { It has the economic potential that will contribute to } \\
\text { increasing the protection or conservation efforts and } \\
\text { community wellness. }\end{array}$ \\
\hline xii & $\begin{array}{l}\text { It has the potential to be a recreational place that will } \\
\text { contribute to increasing the protection/conservation } \\
\text { efforts and economic activities in Medan. }\end{array}$ \\
\hline
\end{tabular}

Source: Authors, 2018

This category of values and criteria has yet to finalized because most respondents thought it should be screened more comprehensively after the group discussion meeting. The result of the workshop showed that about 12 criteria still overlapped and need to be revised for better results and clearer criteria. Therefore, the next step is to develop and screen the criteria during our group discussion meeting by distributing the questionnaire, which is also intended to validate the findings of the study. 


\section{Questionnaire}

The questionnaire was distributed after the group discussion meeting. The feedback from the participants on the 12 criteria are as follows:

- Criterion i can be accepted by all respondents.

- A majority of respondents can accept criterion ii, but with improvements such as eliminating the word 'high level' because it is difficult to measure it. Prefer to use word 'rarity and endangered';

- Criterion iii and iv can be accepted by all respondents with little improvement in the editorial sentence;

- Criterion v can be accepted by the respondents. However, and, some respondents argued it is difficult to determine the indicator, and half of the respondents suggest merging with the criteria vii;

- Only $40 \%$ of respondent agree with criterion vi since it is difficult to determine the indicator so that the evaluation tends to be a more subjective opinion. As a result, it is proposed that criterion vi be removed or merged with criterion vii;

- Criterion vii can be accepted by almost all respondents, but there are proposals for improvement of this criterion by adding the word 'unique' and 'high achievement of a creativity' which is stated in criterion $\mathrm{x}$;

- Criterion viii is acceptable by all respondents, but should be merged with criterion ix;

- Criterion ix can be accepted by some respondents; nevertheless, other respondents argued the meaning and intention of criterion ix already included in criterion viii. By considering this criterion derived from 'use-value,' then, it is proposed to be excluded in valuation.

- Criterion x can be accepted by the respondent, but some respondents suggested it be combined with criterion vii;

- Criterion xi and xii are proposed to be delisted or changed to secondary criteria used after the assessment of cultural heritage significance to develop the policy.

Finally, the respondents concluded there are five main values based on its rank, which are historical value, cultural and spiritual value, scientific value, physical design value, and social values. Educational value, economic value, and recreational value are considered as one of purpose when we conserve cultural heritage. That is why these values do not need to be stated independently and specifically because it should be applied after the designation process. The participants later proposed that the physical design value will cover the uniqueness and rarity value. These values were not included in the assessment of significance and should be used after the process of designation as heritage in the local register. The results of the criteria based on the questionnaire are summarized as follows:

i. It has a strong association with events and important people (warrior, politician, historian, humanist, writer, scientist, philanthropist, and others.) that have played an important part and contributed to the historical development of Medan city.

ii. It has potential information that will contribute to the understanding of the historical development of Medan, and it can be utilized for the present.

iii. It has a strong or special association with a society or community, showing the identity and character of a diverse ethnic and nation.

iv. It possesses rarity in terms of function, design, and craftsmanship.

v. It was a creation or product of a designer, architect, builder, and artist that demonstrated high achievement of creativity, technology or scientific, uniqueness, which has contributed to the cultural and historical development of Medan city.

vi. It demonstrated specific local tradition and represented the local identity or cultural diversity.

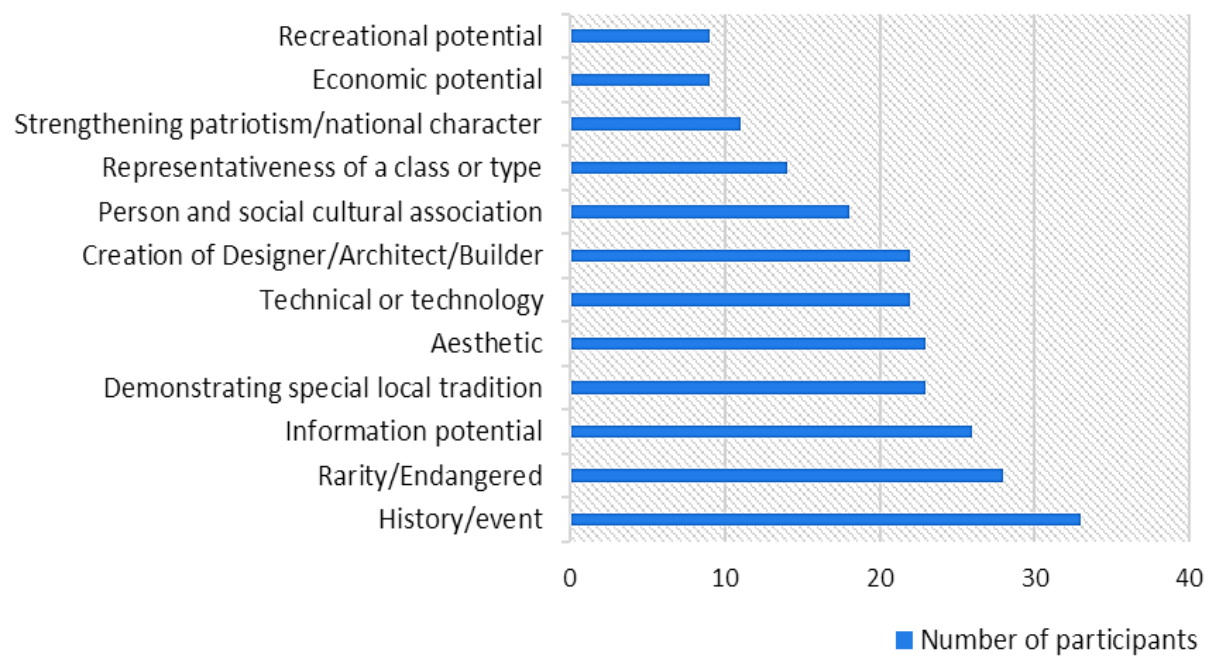

Figure 8. Assessment Criteria resulted by the First Group Meeting

(Source: Authors, 2018) 


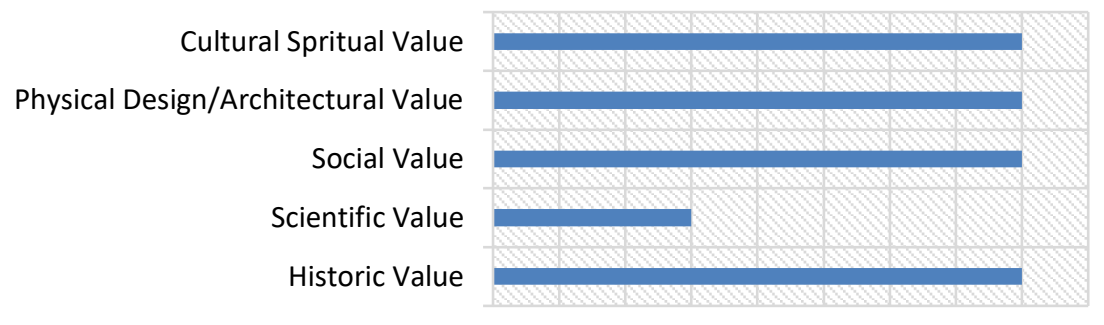

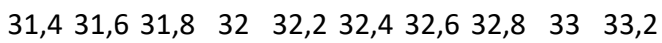

Figure 10. The established criteria based on the questionnaire

(Source: Authors, 2018)

\section{The Second Group Discussion Meeting}

Based on the feedback, a set of values category and criteria for cultural significance assessment of the built heritage of Medan summarized as the research findings. The next stage of study is to confirm the six criteria to the respondents either by email or delivery the hardcopy to the respondent is addressed. This stage is intended to refine and validate the research findings. Table 3 shows the seven samples of the immovable heritage, and the participants are divided into seven groups. Group 1 evaluates the historic area of Merdeka Kesawan, and group 2 evaluates the central post office, as shown in Table 4 and 5 .

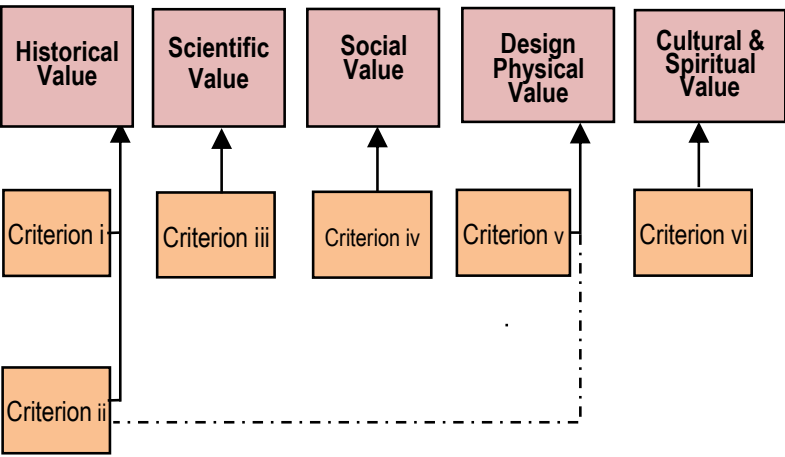

Figure 9. Schematic of Value Types and Criteria for Significance Assessment the Cultural heritage in Medan (Source: Authors, 2018)

Table 4. Group discussion results on assessing the significance of the samples by using the new criteria

\begin{tabular}{cccccccc}
\hline No. & Group 1 & Group 2 & Group 3 & Group 4 & Group 5 & Group 6 & Group 7 \\
\hline Sample & $\begin{array}{c}\text { Merdeka } \\
\text { Kesawan }\end{array}$ & $\begin{array}{c}\text { Central Post } \\
\text { Office }\end{array}$ & $\begin{array}{c}\text { Tjong Afie } \\
\text { Mansion }\end{array}$ & $\begin{array}{c}\text { Grand Mosque } \\
\text { Al Makshun }\end{array}$ & Seri Deli Park & $\begin{array}{c}\text { Tirtanadi } \\
\text { Water Tank }\end{array}$ & Kota Cina Site \\
\hline Category & Historic Area & Building & Building & Building & Park & Structure & Site \\
\hline 1. & NGO1 & NGO2 & NGO3 & NGO4 & NGO5 & NGO6 & NGO7 \\
2. & P1 & P2 & P3 & P4 & P5 & P6 & P7 \\
3. & CM7 & CM6 & CM5 & CM4 & CM3 & CM2 & CM1 \\
4. & G8 & G9 & G10 & NGO14 & NGO13 & NGO12 & NGO11 \\
5. & P8 & P9 & P10 & P11 & P12 & P13 & P14 \\
6. & P15 & NGO9 & NGO8 & P19 & P18 & P17 & P16 \\
7. & G1 & G2 & G3 & G4 & G5 & G6 & G7 \\
\hline
\end{tabular}

Source: Authors, 2018

It shows that criterion ii appeared by all sampling then followed by criterion v, i, vi, and iii. The table above shows that criterion iii appears the lowest of the seven samples. Finally, it concludes there six assessment criteria which are derived from five main values, which are historical value, cultural and spiritual value, scientific value, physical design value, and social values. A historic asset must meet one of them to be included in the heritage listing of Medan. The approach of local community participation in the identification of cultural heritage value is powerful and effective. The selection of respondents from different disciplines and profession make finding more comprehensive research. Based on the process, it is concluded that the method to establish the criteria by involving the local community can figure out, as shown in the next scheme.

Table 5. The range criteria for significance assessment of the seven samples at the second group discussion meeting

\begin{tabular}{c|c|c|c|c|c|c|c}
\hline \multirow{2}{*}{ Criterion } & \multicolumn{7}{|c}{ Sampling } \\
\cline { 2 - 8 } & $\mathbf{1}$ & $\mathbf{2}$ & $\mathbf{3}$ & $\mathbf{4}$ & $\mathbf{5}$ & $\mathbf{6}$ & $\mathbf{7}$ \\
\hline i & $\bullet$ & $\bullet$ & & $\bullet$ & & $\bullet$ & $\bullet$ \\
\hline ii & $\bullet$ & $\bullet$ & $\bullet$ & $\bullet$ & $\bullet$ & $\bullet$ & $\bullet$ \\
\hline iii & & & $\bullet$ & & $\bullet$ & & \\
\hline iv & & $\bullet$ & $\bullet$ & $\bullet$ & & $\bullet$ & \\
\hline v & $\bullet$ & $\bullet$ & $\bullet$ & $\bullet$ & $\bullet$ & $\bullet$ & \\
\hline vi & $\bullet$ & & $\bullet$ & $\bullet$ & & & \\
\hline
\end{tabular}

Source: Authors, 2018 


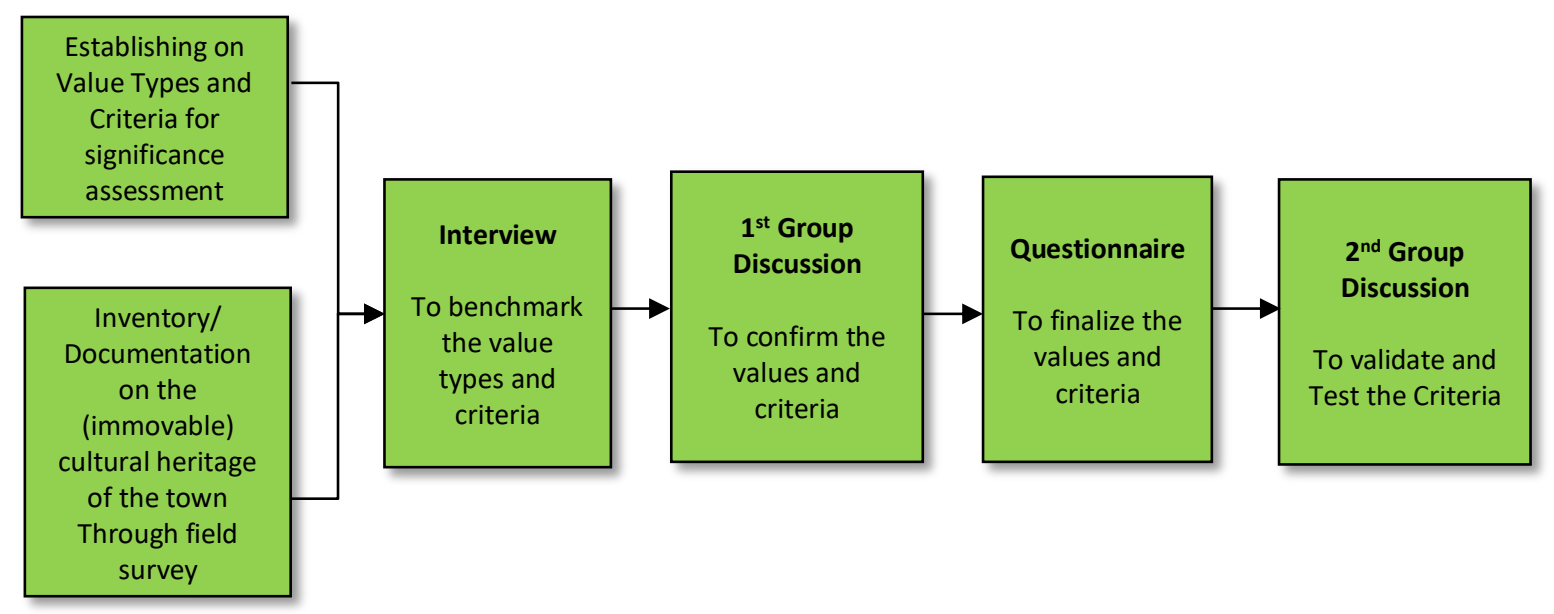

Figure 11. Proposed Method for Establishing the Criteria of Significance Assessment by involving the local community (Source: Authors, 2018)

\section{Conclusion}

The criteria of significance assessment for the cultural heritage in Medan and the evaluation forms can fill up the absence of tool for heritage listing of Medan. The research finding has proved that the criteria of heritage significance assessment can be established by involving the local society or stakeholders generally speaking that they are not categorized as the specialist or experts. Regarding the listing process, the research has found the value typologies which based on the sociocultural value, while the economic value excluded from heritage significance assessment in the gazettal.

The research has found the schematic of value typologies that can help to establish criteria of assessment for the cultural heritage regarding listing or nomination process. Based on the schematic, it helps the authorities or the communities to establish the assessment criteria because it is guiding which are values and sub-values and then sub value types as an array of options for establishing criteria. The method and process to establish the assessment criteria can be applied by other cities in North Sumatra Province and Indonesia region that will be necessary to create assessment criteria for their cultural heritage. It helps and guides the authorities of other cities mainly in North Sumatra Province and other parts of Indonesia to establish their heritage register comprehensively since the absence of cultural significance assessment within the Indonesia Law No. 11 of 2010 up to date.

The study has involved the local people from the beginning of the study. Therefore, carrying out the study is also once has trained and socialized to the local people how to research establishing the criteria for significance assessment since many other cities in Indonesia have no such guideline how to establish their heritage register. This study is limited to find the criteria for significance assessment of the cultural heritage, mainly the immovable cultural heritage in Medan. Nevertheless, in its practical, it needs to detail the principles and indicators derived from each criterion. Therefore, for more comprehensive finding, the following areas are recommended to investigate for future study:

- The development of heritage principles and indicators for significance assessment for every criterion established by the study. The principles and indicators would be guided and assist the assessor in assessing the values of the historic asset. Then, the fewer experience of people can be an assessor.

- Carrying out comprehensive inventory and documentation of the immovable heritage in Medan, including its mapping by using GIS. It can be more helpful to assess the cultural significance of them.

The development of national criteria based on the finding of the study on a critical review of the national heritage list criteria, it includes the principles and indicators for the assessment of the values.

\section{ACKNOWLEDGEMENT}

The authors gratefully acknowledge that the present paper is funded by the Universitas Sumatera Utara, Medan, Indonesia regarding the contract of research skim of TALENTA year 2018 Number: 2590 / UN5.1.R / PPM / 2017 dated March 16, 2018. Part of this paper has been drawn from the author's Ph.D. thesis entitled "Criteria of Significance Assessment for the Cultural Heritage by Involving Local Community Participation in Medan, Indonesia."

$$
* * * * *
$$

\section{REFERENCES}

AICOMOS. (2013). Burra Charter (The latest Revision). ICOMOS, Australia (Revised in 1981, 1999, and 2013). Retrieved from http://australia.icomos.org/

Appiah, A. K. (2006). Cosmopolitanism: Ethics in the world of strangers. New York: W. W. Norton. 
Australian Heritage Council. (2010). Identifying Commonwealth Heritage Values and Establishing a Heritage Register: a guideline for commonwealth agencies. Retrieved from http://www.environment.gov.au/

Avrami, E., Mason, R., \& Torre, M. (2000). Values and Heritage Conservation: Research Report. Los Angeles: The Getty Conservation Institute.

China ICOMOS. (2015). Principles for the Conservation of Heritage Sites in China. Los Angeles: The Getty Conservation Institute.

Chirikure, S., Pwiti, G., Damm, C., Folorunso, C. A., Hughes, D. M., Phillips, C., ... \& Pwiti, G. (2008). Community involvement in archaeology and cultural heritage management: An assessment from case studies in Southern Africa and elsewhere. Current Anthropology, 49(3), 467-485.

Clark, K. (2014). Values-based heritage management and the Heritage Lottery Fund in the UK. APT Bulletin, Journal of Preservation Technology, 45(2-3), 65-71.

Clark, K., \& Maeer, G. (2008). The cultural value of heritage: evidence from the Heritage Lottery Fund. Cultural Trends, 17(1), 23-56.

Dian, A. M., \& Abdullah, N. C. (2013). Public participation in heritage sites conservation in Malaysia: Issues and challenges. Procedia-Social and Behavioral Sciences, $101,248-255$.

Engelhardt, R. A., \& Rogers, P. R. (2009). Hoi An Protocols for Best Conservation Practice in Asia: Professional Guidelines for Assuring and Preserving the Authenticity of Heritage Sites in the Context of the Cultures of Asia. Bangkok: UNESCO Bangkok.

English Heritage. (2008). Sustaining the historic environment. In Graham Fairclough, Rodney Harrison, John H. Jameson Jnr \& J. Schofield (Eds.), The Heritage Reader. New York: Routledge.

Fitri, I., Ahmad, Y., \& Ahmad, F. (2015). Conservation of Tangible Cultural Heritage in Indonesia: A Review Current National Criteria for Assessing Heritage Value. Procedia-Social and Behavioral Sciences, 184, 71-78.

Fitri, I., \& Yahaya. (2017). Identification and Documentation of the Immovable Cultural Heritage in Medan City, North Sumatra. Proceeding the 2nd International Nusantara Cultural Heritage (INCH) Symposium (pp.146-150). Padang.

Frey, B. S. (1994). Cultural Economics and Museum Behaviour. Scottish Journal of Political Economy, 41, 325-335.

ICOMOS. (1987). Charter for the Conservation of Historic Towns and Urban Areas (Washington Charter). Retrieved from http://www.international.icomos.org/

ICOMOS. (1996). Principles for the Recording of Monuments, Groups of Buildings and Sites. The 11th ICOMOS General Assembly in Sofia. Retrieved from http://www.icomos.org/

Johnson, N. (2000). Historical Geographies of the Present. In B. Graham \& C. Nash (Eds.), Modern Historical Geographies (pp. 251-72). Harlow: Prentice Hall.

Jokilehto, J. (2005). Definition of Cultural Heritage: References to documents in history. ICCROM Working Group Heritage and Society, 4-8.

Kerr, J. S. (2013). The Seventh Edition Conservation Plan, A Guide to preparation plans for places of European Cultural Significance. Sydney: Australian ICOMOS.

Lipe, W. D. (1984). Value and Meaning in Cultural Resources. In H. Cleere (Ed.), Approaches to the Archaeological Heritage (pp. 1-11). Cambridge: Cambridge University Press.
Lithgow, K., \& Thackray, D. (2009). The National Trust's approach to conservation. Conservation Bulletin, 60, 1619.

Macdonald, S., \& Ostergren, G. (2011). Developing a Historic Thematic Framework to Assess the Significance of Twentieth-Century Cultural Heritage: An Initiative of the ICOMOS International Scientific Committee on Twentieth-Century Heritage. An Expert Meeting Hosted by the Getty Conservation Institute ed. Los Angeles, CA: The Getty Conservation Institute.

Mason, R. (2002). Assessing Values in Conservation Planning: Methodological Issues and Choices. In Marta de la Torre (Ed.), Assessing the Values of Cultural Heritage (pp. p.5-30). Los Angeles: The Getty Conservation Institute.

Mason, R. (2008). Assessing Value in Conservation Planning. Methodological Issues and Choices. In Graham Fairclough, Rodney Harrison, John H. Jameson Jnr \& John Schofield (Eds.), The Heritage Reader (pp. 95125). New York: Routledge.

O'Connor, Z. (2011). Valuation of Cultural Heritage: toward a conceptual model and potential evaluation strategies. In Mittleman D., \& Middleton D. A. (Eds.), The 42nd Annual Conference of the Environmental Design Research Association (pp. 189-196). Chicago: Environmental Design Research Association.

Orbasly, A. (2008). Architectural Conservation, Principle and Practice. Oxford: Blackwell Publishing.

Rand, E., \& Chabbi, A. (2007). Recording, Documentation, and Information Management for the Conservation of Heritage Places, lllustrated examples. Los Angeles, CA: The Getty Conservation Institute.

Riganti, P., \& Nijkamp, P. (2004). Valuing Cultural Heritage Benefits to Urban and Regional Development. Paper presented at the 44th European Congress of The European Regional Science Association Regions and Fiscall Federalism. Porto: University of Porto.

Stovel, H. (2002). An Advisory Body View of the Development of Monitoring for World Cultural Heritage. In Venice Congress Proceedings Monitoring World Heritage (pp. 17-21). Vicenza: UNESCO World Heritage Centre.

Tomback, D. H. (2007). Valuing our heritage. In M. Forsyth (Ed.), Understanding Historic Building Conservation (pp. 204-210). Victoria: Wiley-Blackwell.

Undang-Undang RI. UU tentang Cagar Budaya, Pub. L. No. 11 (2010). Indonesia.

UNESCO. (1976). Nairobi Recommendation: International Recommendation concerning the Safeguarding and Contemporary Role of Historic Areas. Retrieved from http://www.icomos.org/

Venice Charter. (1964). International Charter for the Conservation and Restoration of Monuments and Sites. Venice.

World Bank. (1994). Final Report of the Participatory Development Learning Group. NW Washington, DC: World Bank.

Worthing, D., \& Bond, S. (2008). Managing Built Heritage: The Role of Cultural Significance. Oxford: WileyBlackwell.

Zancheti, S. M., Hidaka, L. T. F., Ribeiro, C., \& Aguiar, B. (2009). Judgment and Validation in the Burra Charter Process: Introducing feedback in assessing the cultural significance of heritage sites. City \& Time, 4(2), 47-53.

Zerrudo, E. B. (2008). The Cultural Mapping Project of the Heritage City of Vigan: Towards building a Framework for Heritage Conservation and Sustainable Development. Paper presented at the 3rd International Memory of the World Conference. Canberra: UNESCO Australia. 